Милош Д. Ђурић

Универзитет у Београду

Електротехнички факултет

djuric@etf.bg.ac.rs

https://doi.org/10.18485/ai_knjiz_u_prevodu.2019.ch5

$81^{\prime 2} 255.4$

821.163.41.09-1 Максимовић Д.

\title{
ПРЕВОЂЕЊЕ ПОЕЗИЈЕ ДЕСАНКЕ МАКСИМОВИЋ СА СРПСКОГ НА ЕНГЛЕСКИ ЈЕЗИК
}

У раду се даје кратак осврт на превођење поезије Десанке Максимовић са српског на енглески језик. У првом делу рада дају се уводне напомене у кратким цртама, а онда и извесне одлике поезије Десанке Максимовић. У наставку следи кратак опис теоријских модела који се примењују (генеративна поетика, математичка поетика, структуралистичка поетика, теорија релевантности), а потом се укратко описује корпус превода. У другом делу рада вршимо анализу превода песме Крвава бајка Десанке Максимовић на енглески језик. У овом делу рада анализирају се преводилачка решења. У трећем делу рада износе се закључне напомене.

Кључне речи: Десанка Максимовић, поезија, превођење поезије, преводни еквиваленти, Крвава бајка, теорија релевантности, структуралистичка поетика, прагматичко обогаћење.

\section{1. Уводне напомене}

Тема овог рада је превођење поезије Десанке Максимовић са српског на енглески језик. Због просторног ограничења, анализираћемо детаљније песму Крвава бајка, и пет превода на енглески језик. Али, пре него 
што анализирамо пет превода поменуте песме, погледаћемо како се превођење поезије третира у релевантној литератури. Потом следи концизно дескриптивно тумачење различитих поетика (у фокусу су: генеративна, математичка и структуралистичка поетика, а потом и теорија релевантности примењена на превођење поезије). Пре анализе превода на енглески језик, погледаћемо и неке опште одлике поезије Десанке Максимовић.

Пошавши од констатације, која се износи у литератури, да „превођење поезије поставља још веће захтеве пред преводиоца него превођење уметничке прозе” (Konstantinović 1981: 119), анализирали смо преводе поезије песникиње Десанке Максимовић. У цитираној литератури, констатује се да приликом превођења поезије тешкоће могу представљати преношење смисла, али и стилских вредности које проистичу из разлика између изворног, тј. полазног језика и језика превода, тј. циљног језика. Такође, у песничком делу јавља се и не мање битан изазов за преводиоца, а то је репродуковање форме. Постоје аутори који кажу да „проблеми превођења постају нарочито сложени у превођењу поезије у ужем смислу" (Сибиновић 1979: 150). Цитирани аутор констатује да се приликом превођења поезије мора обратити пажња на еуритмијске, еуфонијске и синтаксичке структуре песничког исказа.

Такође, нашу истраживачку пажњу је привукло управо превођење поезије, нарочито због констатације, која се износи у релевантној литератури, да се, нарочито последњих година, веома мали број академских радова посвећених књижевном превођењу усредсређује на поезију као књижевни облик (Tanasescu 2016: 1). У литератури се превођење поезије ближе одређује као преношење поезије путем релеја на други језик (Jones 2011: 1). Често се увиђају и тешкоће, па чак и немогућ- 
ности приликом превођења поезије. Као што се ни за једну песму не може рећи да је икада завршена, тако је и преведена песма отворена за измене (Born 1990: 227). Борнова експлицитно каже да уколико превођење посматрамо као креативан облик писања, што свакако мора бити случај нарочито са поезијом, онда сваки преводилац пише различиту песму, а ауторка и сама наводи у својој песми о превођењу да није довољно „пренети” речи и значења (Born 1990: 227):

You can't transport him lock, stock, barrel, as found, he must be rebuilt on your own ground.

Ова ауторка у фокус своје студије доводи једно „вечно” питање, а то је да ли испољити потпуну верност оригиналу, или пак извршити маштовиту реконструкцију оног што преводилац види као смисао који се може преузети из песме. Она се, веома умесно, позива на познат пример превода Дантеове Божанствене комедије, најпре у преводу Дороти Сејерс и делова које је превео далеко слободније Симус Хини. Дакле, видимо да постоје, још увек, различита колебања када је у питању превођење поезије.

Следећи изазов који се ставља пред преводиоца поезије јесте одлука да ли преводилац треба да преводи стихове прозом или да преводи стихове у стиху (Сибиновић 1979: 154). Но, одговор на ово или слична питања налазимо у неким ставовима који се износе у литератури, као што неки аутори сматрају да преводиоци могу да имају „[...] више маневарског простора за спровођење у дело личних афинитета" (Hlebec 1989: 78), па између осталог, могу и да одлуче да ли ће преводити стихове прозом или у стиху. Управо доношење оваквих одлука чини превођење поезије комплексним. 
Али, уз то, треба још имати на уму и нестандардни редослед реченичних елемената и различите инверзије које се често сусрећу у поезији, што додатно отежава превођење поезије. Међутим, како се то констатује у литератури, „без некаквог извртања или рушења језичких норми не би било поезије" (Vukobrat 1986: 161).

У наредном одељку погледаћемо неке одлике поезије Десанке Максимовић, углавном према релевантној литератури.

\section{1. Одлике поезије Десанке Максимовић}

Одлука да одаберемо управо чувену српску песникињу Десанку Максимовић донели смо због особености њеног песништва, али и истрајности у њеном личном развојном путу. Посебан изазов за преводиоце на енглески језик представља и специфичност њеног поетског поступка приликом стварања својих песама. Овај изазов који се ставља пред преводиоце нарочито представља специфичан поетски модел поезије Десанке Максимовић, који је, према литератури, „[...] увек био посебан у односу на савременике; од првих песама објављених почетком двадесетих година до последњих збирки и песама деведесетих година [ХХ века]" (Шеатовић 2018: 75).

О значају Десанке Максимовић за српску поезију писано је доста, па није потребно да наглашавамо њено посебно место у српској књижевности, или специфичније поезији XX века. Чини се као да је Десанка Максимовић ишла једном добро утабаном, али одвојеном стазом у сопственом развоју током писања поезије. Онда није ни зачуђујуће што се у релевантној литератури констатује да Десанка Максимовић „[...] представља пример јединственог опуса у оквиру српске књижевности 20. века" (Шеатовић 2018: 75). У литератури се на- 
води и да је Десанка Максимовић аутор поезије идентитета (Марковић 2018: 121), што је битан моменат како за анализу њеног поетског опуса, тако и за превођење истог на стране језике.

Након што смо имплицитно назначили улогу Десанке Максимовић у српској књижевности, погледајмо и како се њена поезија одређује у радовима који се баве њеним песничким опусом. Према релевантној литератури, поезија Десанке Максимовић се одређује као искрена поезија нежног сензибилитета и непосредног казивања (Марковић 2018: 121). Према литератури, поезија Десанке Максимовић писана је „[...] слободним стихом, новим духом и сензибилитетом песника 20-их година 20. века, али без оповргавања традиције као што ће то радити авангардисти [...]" (Шеатовић 2018: 71). Поезија Десанке Максимовић обилује различитим нијансама, импресијама, синестезијама карактеристичним за симболизам, а управо користећи такву способност „[...] да ухвати детаљ природе и човека" (Шеатовић 2018: 71) довео је до наше можда најлепше поезије након модернизма.

Надаље, према литератури, поезија Десанке Максимовић се одређује као „[...] изразито субјективна, интимна [...]", али не и интровертна. Напротив, њена поезија је отворена „[...] према природи, другим људима, свету - и све то обојено је личним виђењем и толином доброте и човекољубља; присношћу, мекотом и болећивошћу" (Марковић 2018: 121). Сем тога, у вези са особеностима њене поезије, у литератури се износи и да је у развоју српске поезије Десанка Максимовић „[...] остала симбол лирске суптилности, трајања и популарности” (Шеатовић 2018: 75-76).

Управо лирска суптилност и аутентични лирски глас Десанке Максимовић чини њену поезију изазовном за превођење на енглески језик. Још један изазов за преводиоце поезије Десанке Максимовић на енгле- 
ски језик лежи у следећој особености њене поезије, која је примећена и изнета у литератури. Наиме, „Десанка Максимовић не бежи од сопствене личности, не крије се иза фиктивног лирског субјекта [...]" (Марковић 2018: 121). Све ово чини поезију Десанке Максимовић комплексном и стога није ни чудо да њена поезија представља прави изазов за преводиоце. У наредном делу погледаћемо теоријске моделе и методе који су консултовани и/или коришћени приликом анализе.

\section{2. Генеративна поетика}

У оквиру генеративне поетике истиче се поетска граматичност, иако се у литератури тврди да је Чомски највише обраћао пажњу на однос између семантике и синтаксе приликом сагледавања поетског дискурса (Thomas 1978: 37). У оквирима генеративне поетике, извесни аутори настоје да успоставе језичку основу поетског језика, па самим тим, не постављају питање о ваљано обликованим фразама, пошто њихово деловање проналази место на нивоу поетске способности. У литератури која се бави генеративном поетиком, поетска способност ${ }^{1}$ (фp. compétence poétique) се одређује као скуп правила која су подложна генерисању ваљано обликованих фраза као и фраза које одступају од ваљане обликованости (Thomas 1978: 21). У том смислу, постоји простор и за стилске фигуре у оквиру генеративне граматике, па самим тим и генеративне поетике, што је релевантно, нарочито за анализу поезије.

Када се говори о стилским фигурама у оквирима генеративне граматике пореде се генеративна грамати-

1 Овде смо се одлучили за један од три преводна еквивалента за енглески термин competence, односно француски compétence, који се нуде у релевантној лингвистичкој литератури: знане, способност и умеће (Tomović 2010: 137). 
ка Пор Ројала и генеративна граматика Ноама Чомског (Delas 1978: 65). У наставку се, веома умесно, констатује да се не може са лакоћом говорити о рђаво обликованим, девијантним фразама, пошто се не може негирати чувена илустрација аграматичности коју проналазимо у реченици Colourless green ideas sleep furiously (Безбојне зелене идеје бесно спавају리, а која је атестирана у књижевном корпусу (Delas 1978: 65).

Генеративна поетика посвећује пажњу макроструктурама у деривацији целокупног текста, а у поетским анализама помиње се и густина у поезији. Такође, у литератури се наводи да је могуће изоловати специфичне језичке особине које прате нашу интуицију о поезији и то на примеру поезије Емили Дикинсон (Delas 1978: 94). Генеративна поетика омогућава читање које осветљава логичке везе које постоје унутар две пропозиције у оквиру песме. На том примеру, каже се да изостављање субординираног везника јесте додатни фактор који производи осећај густине. Генеративна поетика пружа нам спознаје које омогућавају и анализу лирске поезије, између осталог, а такође и анализу превода поезије уопште. У наредном одељку погледаћемо неке карактеристике математичке поетике.

\section{3. Математичка поетика}

У оквиру математичке поетике основна питања односе се на разлике између математике и поетског језика. Према литератури из домена математичке поетике налазимо следеће тврдње: поетски језик поседује бесконачну двосмисленост, а математички не познаје недвосмисленост. Затим, лирско значење је континуал-

2 Превод наведене реченице на српски језик: Ранко Бугарски. Види: Bugarski (1996: 220) 
но, а математичко је дискретно; песнички језик врши функцију сугестије, а математички појмовну функцију. Коначно, лирски акт је рефлексиван, а математички транзитиван (Markus 1974: 20). У оквиру математичке поетике обраћа се пажња, између осталог, на структуру семантичког језика, ритамске структуре, ритамске дужине и ритамски индекс, ритамски дијаметар и ритамску димензију, као и природу лирског значења.

Када се говори о неколико топологија придружених једном лирском језику, у овом теоријском моделу констатује се да „[...] процес комуникације у лирском језику није једноставно кодификовано преношење неког значења [...]" (Markus 1974: 117). Релевантно за превођење поезије може бити схватање преноса лирске поруке. Наиме, у оквиру математичке поетике, констатује се да се лирска порука може схватити „[...] кроз процес апроксимације, понекад путем асимптотичког приближавања, а то приближавање претпоставља могућност да се дефинишу околине неког значења и евентуално чак и појам растојања између њих" (Markus 1974: 117). Цитирани аутор наводи да прецизирање оваквих ситуација неизбежно води ка увођењу извесних тополошких структура, чак и метричких, у скуп $\Sigma$. Дакле, видимо да нам и математичка поетика пружа могућности и солидне основе за поетску анализу, али и превођење поезије са полазног на циљни језик.

У следећем одељку погледаћемо структуралистичку поетику и могућност њене примене на анализу поетског дискурса.

\section{4. Структуралистичка поетика}

Структуралистичка поетика даје предност генеративној граматици, а за трансформациону граматику, 
макар када су у питању примене лингвистичких модела и метода на анализу поетског језика, констатује да „[...] граматике нису биле трансформационе и нема разлога за наметање таквог захтева структуралистима" (Калер 1990: 47). Иако критикује Јакобсонове поетске анализе, Џонатан Калер их користи да илуструје примену лингвистичког метода у проучавању књижевности. Овај аутор констатује да би једноставан поступак био „[...] коришћење категорија лингвистике за опис језика књижевних текстова” (Калер 1990: 91). Надаље, овај аутор констатује да је књижевност, пре свега, језик, а пошто је структурализам заправо метод заснован на лингвистици, највероватнија додирна тачка је сама лингвистичка грађа, констатује Калер, парафразирајући Женета (Калер 1990: 91).

У оквиру структуралистичке поетике указује се на важност синтаксичког паралелизма и граматичких тропа у поезији, и ту се централна улога приписује Јакобсону. Међутим, оно што се имплицитно критикује јесу дистинктивна обележја поетске употребе језика, али се не пренебрегавају начини на који су строфе повезане симетричним распоредом граматичких јединица. Другим речима, иако критикује Јакобсонове поетске анализе, Калер им не оспорава значај приликом изузетно формалне анализе поезије.

Када анализира поетику лирске песме, структуралистичка поетика истиче да смо „[ч]итајући поезију, склони [...] не само да прихватимо формалне обрасце већ да од њих створимо нешто више од украса везаних за саопштљив говор" (Калер 1990: 245). Раван у којој се сусрећу генеративна поетика и структуралистичка поетика, чини се да је управо она где се приликом анализе фокусира на густину (у генеративној поетици), односно на дистанцу и деиксу (у структуралистичкој 
поетици). Поред дистанце и деиксе (Калер 1990: 241), структуралистичка поетика узима у обзир органске целине, тему и епифанију, резистенцију и рекуперацију (Калер 1990: 255-282).

У наредном одељку погледаћемо теорију релевантности и могућност њене примене у превођењу поезије.

\section{5. Теорија релевантности и превођење поезије}

Постоје мишљења, која се износе у литератури, да се процес превођења може објаснити у оквирима теорије релевантности ${ }^{3}$ Спербера и Вилсонове, те стога не постоји потреба за оделитом општом теоријом превођења (Gutt 1990: 135). Цитирани аутор барата, између осталог, и појмом интерпретативне употребе, која је битна у овом теоријском оквиру. Парафразирајући Спербера и Вилсонову (Sperber \& Wilson 1988), овај аутор каже да постоје два фундаментално засебна начина на које се искази и репрезентације могу општије користити. Наиме, оне се могу користити дескриптивно као стање ствари у систему, или пак, интерпретативно, на основу њихове сличности са неком другом репрезентацијом (Gutt 1990: 146). Цитирани аутор сматра да у оквиру теорије релевантности битан фактор јесте интерпретативна употреба. Другим речима, приликом превођења, преведени искази интерпретативно личе на оригиналне исказе, зато што деле експликатуре и/ или импликатуре оригиналног, тј. изворног текста.

3 Одлучили смо се за преводни еквивалент теорија релевантности, зато што одговара фонотактичким правилима српског језика. Сем тога, у пионирској питератури, која први пут помиње ову теорију на српском језику, користи се управо преводни еквивалент теорија релевантности (види: Polovina 1996; Žegarac 2005). Поред тога, овакав преводни еквивалент јавља се и у Глосару теорије релевантности: српско-енглеском (види: Đurić \& Krnjaić-Cekić 2016). 
У оквиру теорије релевантности фигурирају два принципа: први, тј. когнитивни принцип релевантности и други, тј. комуникативни принцип релевантности. С обзиром на просторно ограничење рада, изнећемо само укратко следеће пертинентне информације. Први принцип гласи: Људски когнитивни процеси су усмерени ка обради најрелевантније расположиве информације на најрелевантнији начин (Sperber \& Wilson 1995: 260; превод са енглеског: Милош Д. Ђурић \& Нада Крњаић-Цекић), а други принцип гласи: Сваки чин демонстративне комуникације саопштава претпоставку о сопственој оптималној релевантности (Sperber \& Wilson 1995: 260; превод са енглеског: Милош Д. Ђурић \& Нада Крњаић-Цекић). Ова два принципа имају реперкусије, између осталог, и на процес превођења, а могу се директно применити у теорији и пракси превођења.

У овом теоријском оквиру, фигурира и концепт интерпретативне сличности (енг. interpretive resemblance) ${ }^{4}$. У овим случајевима, превод кодира али не оно што је било кодирано у оригиналу, већ преводиочеву интерпретацију онога што би изворни концепт требало да саопшти (Rosales Sequeiros 2001: 197). Према цитираном аутору, до дискрепанце у преводу често долази услед ефекта интерпретативне сличности између онога што је кодирано и онога што се саопштава. Слично томе, Спербер и Вилсонова су такође установили да долази до интерпретативне сличности када две пропозиционе репрезентације деле своје аналитичке и контекстуалне импликације у датом контексту (Sperber \& Wilson 1988: 138). Према литератури, један од главних типова интерпретативне сличности у преводу јесте сличност међу

4 Преводна решења (нпр. интерпретативна сличност) узимали смо из Глосара теорије релевантности Милоша Д. Ђурића и Наде Крњаић-Цекић (види: Đurić \& Krnjaić-Cekić 2016). 
концептима, односно између кодираног и саопштеног концепта (Rosales Sequeiros 2001: 197-198). Овај проблем се разрешава тако што се саопштени концепт одређује путем прагматичке интерпретације.

Аутори који примењују теорију релевантности на превођење поезије истичу снагу овог когнитивног модела који може да понуди одличне алате за објашњење процеса који се врше приликом превођења књижевности (Mateo 2009: 1). У оквиру теорије релевантности примењене на превођење поетског дискурса, констатује се да су слабе импликатуре типичне за поетске текстове, што захтева веће инференцијалне напоре од стране реципијената него што је то случај код осталих књижевних текстова.

У цитираној литератури се узима у обзир и додатни проблем, а то је да писани дискурс не помаже да се обраде сва његова значења, а обично је мање демонстративан, мање процедуралан и више концептуалан него усмени дискурс. У оквиру примене теорије релевантности на превођење поезије, узимају се у обзир следећи критеријуми и параметри. Преведени текст (ПТ) требало би да покуша да пренесе исто или слично значење као изворни текст (ИТ), што имплицира да преводилац треба да користи еквивалентан пропозициони садржај који дозвољава слично дескриптивно декодирање. Надаље, ПТ треба да произведе код читалаца исте или сличне когнитивне ефекте као оне што производи ИТ. Другим речима, ПТ треба да обезбеди демонстративност, стимулансе и контекстуалне ефекте еквивалентне онима у ИТ, на тај начин омогућавајући реципијентима ПТ сличну интерпретативну инференцију. Можда је најрелевантнији критеријум да стилска обележја, односно поетски ефекти, који се испољавају у ИТ треба да паралелно постоје и у ПТ. Коначно, ПТ би требало да изврши адекватну лексичку селекцију, и (ако је могуће) 
граматички распоред као у ИТ, енкодирајући скуп пропозиција сличних онима у ИТ (Мateo 2009: 3).

Као што то констатује цитирани аутор, велики део интерпретативног превођења, које се усредсређује на оригинални квалитет књижевних текстова, захтева од преводилаца да уложе велике напоре у потрази за преводним еквивалентима који испољавају верност оригиналног текста. А, као што је то истакнуто у литератури, слабе импликатуре и поетски ефекти чине књижевне текстове, а нарочито поезију суптилном и вишезначном (Mateo 2009: 4), што даље усложњава процес превођења поезије.

У наредном одељку, погледаћемо критику превода поетских дела, према релевантној литератури.

\section{6. Критика превода поетских дела}

У оквиру критике превода поетских дела констатује се да је код превођења поетских дела, „[...] процес трансформације изворника неупоредиво сложенији, због дубље везаности поетског израза за непроменљиву природу језика" (Bertolino 1981: 159). У критици превода поетског дела, чини се као централно питање да ли треба оцењивати превод и као самостално поетско дело, заборављајући да је оно настало процесом превођења. Цитирани аутор закључује да права критика превода поетских дела може бити „[...] само она која, уместо од изворника ка преводу, полази од превода ка изворнику, заборављајући, бар у једном тренутку, постојање овог другог и оцењујући књижевну вредност превода као самосталног поетског дела" (Bertolino 1981: 161).

Бертолино додаје још и да сама тежина задатка преводиоца поетског дела у великој мери зависи од тога 
колико разлике између језика отежавају директно искоришћавање изворника као унутрашњи модел дела које преводилац треба да створи на језику на који преводи. Критика превода се бави и оценом блискости или удаљености превода од оригинала, а оцењује се и са̂м процес превођења. У овом теоријском оквиру, Бертолино види критичара превода као некога ко се може потрудити да помогне читаоцу, тако што би уочавао оно што је битно и карактеристично у том изузетно сложеном сплету односа оригинала и превода (Bertolino 1981: 173).

У наредном делу дајемо кратак опис корпуса који нам је послужио за анализу превода поезије Десанке Максимовић.

\section{7. Кратак опис корпуса}

У овом одељку дајемо сажет преглед корпуса како би се стекао јаснији увид у адекватност корпуса који смо користили у анализи превода поезије Десанке Максимовић на енглески језик. Корпус обухвата књигу изабраних песама преведених на енглески језик: Desanka Maksimović. Don't Fear. Selected Poems (Maksimović 1998). Овај корпус обухвата 239 страна штампаног текста.

Поред овог примарног корпуса, користили смо и секундарни корпус у електронском облику на интернет мрежи који смо конвертовали у Word 2007 документ који обухвата 7 страна, 1056 речи, 258 редова. Овај корпус чине 4 превода песме Крвава бајка. Пети превод, који ће бити под нашом истраживачком лупом, налази се у претходно наведеној збирци.

У наредном делу анализирамо пет превода песме Крвава бајка са српског на енглески језик. 


\section{2. Анализа превода песме Крвава бајка}

Десанке Максимовић на енглески језик

У овом делу рада анализирамо пет превода песме Крвава бајка Десанке Максимовић на енглески језик. Но пре него што кренемо са анализом, најпре ћемо погледати неке карактеристике, које се, према релевантној литератури (Solar 1981: 128-151; Živković 1992: 106$117)$, иначе узимају у обзир приликом анализе песама.

Дакле, узимајући одређења из цитиране литературе која даје основне параметре за анализу лирских песама, можемо одредити песму Крвава бајка као родољубиву лирску песму у чијем фокусу се налази исказивање туге и бола због страдања крагујевачких ђака. Ако се посматрају формални елементи које предлаже литература (Solar 1981; Živković 1992) онда се Крвава бајка може посматрати и као елегија.

Тема песме је заснована на истинитом догађају, који се одиграо октобра 1941. године у Крагујевцу (познатије као Крагујевачки масакр), када су немачки окупатори убили неколико хиљада људи, а између осталих и ђаке Крагујевачке гимназије у знак освете због убиства и рањавања неколицине немачких војника. Основни мотив у песми је злочиначки и нељудски чин немачког окупатора према недужним грађанима Крагујевца. Поред ових формалних елемената, могуће је успоставити паралелу између бајке и поезије. Иако је, према литератури, бајка заправо строго утврђена књижевна врста, односно „[...] врста с релативно строго утврдивим конвенцијама изражавања”, ипак се бајка „[...] у много чему приближава поезији [...]” (Solar 1981: 162).

Структурно посматрано, песма Крвава бајка се састоји од седам строфа. Прва, трећа и пета строфа се понављају, па се може рећи да, према критеријумима теорије књи- 
жевности (Solar 1981; Živković 1992), представљају рефрен песме. Мада се може уочити мала разлика између ових строфа, пошто се синтагма мученичка смрт у петој строфи трансформише у синтагму јуначка смрт.

Током анализе превода песме Крвава бајка погледаћемо жанровске особености и језичко-стилска средства, која ће бити коментарисана само уколико их је потребно призвати у помоћ ради анализе превода. Свакако овде треба имати на уму и одређења која се наводе у релевантној литератури, а према којима је бајка особита књижевна врста у којој се „[...] чудесно и наднаравно испреплеће са збиљским на такав начин да између природног и натприродног, стварног и измишљеног, могућег и немогућег, нема правих супротности" (Solar 1981: 162).

Дакле, предмет анализе јесу пет превода песме Крвава бајка са српског језика на енглески језик. Преводи који су предмет анализе биће означени следећом нотацијом: 1. А. Ленарчић \& Ј. Лаврин (1ЛЛ), 2. Драгана Константиновић (2ДК), 3. Павле Нинковић (3ПН), 4. Sarah O'Keeffe (4SOK) и 5. анонимни преводилац (5A).

Најпре погледајмо како су преводиоци превели са српског на енглески саิм наслов песме Крвава бајка. Први преводилац се одлучио за A Legend of Blood (1ЛЛ), други преводилац се одлучио за Bloody Fairy Tale (2ДК), трећи преводилац се одлучио за A Bloody Fairytale (3ПН), четврти преводилац се одлучио за $A$ Bloody Fairytale (4SOK), а пети преводилац се одлучио за Tale of Victims (5A). Примећујемо да 2ДК, ЗПН и 4SOK имају скоро идентичан превод, с тим што 2ДК избегава употребу члана, док 3ПН и 4SOK користе неодређени члан $а$ испред синтагме. И код 2ДК и $3 П Н$ и $4 \mathrm{SOK}$ je употребљена сложеница, с тим што је код 4SOK ортографски фузионисана (Fairytale), 3ПН користи верзију 
са цртицом (Fairy-tale), а код 2ДК је одвојена белином (Fairy Tale) $)^{5}$.

У преводу 1ЛЛ користи се именица legend, а у преводу 5А именица tale, којој претходи неодређени члан a. Треба водити рачуна о одабиру контекстуално прилагођеног одговарајућег енглеског преводног еквивалента за семантичку јединицу бајка, имајући у виду да песма Крвава бајка, не само због наслова, већ и због жанровских карактеристика, има све параметре који припадају књижевној врсти бајке. Наиме, садржи почетак карактеристичан за бајке, односно прецизније, започиње стихом „Било је то у некој..., који се затим понавља три пута (карактеристично понављање три пута у бајкама, као и број три, карактеристичан за бајке), а садржи и доминантну категорију давно прошлог времена. Сем тога, уколико погледамо монолингвални речник савременог енглеског језика уочавамо следећа одређења. За лексему legend LDOCE наводи следеће одређење: „an old well-known story, often about brave people, adventures, or magical events" и наводи синоним myth. С друге стране, за лексему fairy tale LDOCE наводи следеће одређење: „1. a children's story in which magical things happen; 2. a story that someone has invented and is difficult to believe". LDOCE даје следеће одређење за лексему tale: „1. a story about exciting imaginary events; 2 . a description of interesting or exciting things that happened to someone, often one which is not completely true about every detail". Овде видимо на делу оно што се помиње

5 Овакве различите графичке реализације једне исте сложенице дозвољавају дескриптивне граматике савременог енглеског језика. На пример, GCE наводи примере једне исте сложенице која се легитимно може писати на три начина која су прихватљива: flowerpot, flower-pot и flower pot, односно, 1. фузионисано, 2. са цртицом и 3. са белином (размаком) између графичке масе. 
у литератури да „[...] речи привидно подударне денотације имају често различите конотације, тојест различит семантички профил" (Vukobrat 1986: 161). Имајући у виду да песма почиње формулом бајке, овде је адекватно употребљен преводни еквивалент „fairy tale”, за који су се определили преводиоци 2ДК, 3ПН и $4 \mathrm{SOK}$. Преводни еквивалент „fairy tale” можда више одговара контексту у односу на лексеме „legend” и „tale”. Надаље, када је у питању наслов и превођење придева крвава, преводиоци 1ЛЛ, 2ДК, 3ПН, и 4SOK одлучили су се да овај придев преведу: of blood (1ЛЛ), bloody (2ДК, ЗПН и $4 \mathrm{SOK})$, док се 5А одлучио за именицу у плуралу victims, односно нигде не користи неки облик који би садржао blood. Погледаћемо како су преводиоци одлучили да преведу први стих, с обзиром на релевантност истог за даљи ток песме.

У оригиналу, песма почиње формулом бајке стихом „Било је то у некој земљи сељака”. Дакле, имамо инверзију која производи ефекат бајке, као и конструкцију „било је + (некада, негде, нешто)” која је опет карактеристична за бајке. Преводиоци 1ЛЛ су се одлучили за "It happened in a far-off land of peasants", а преводилац 2ДК се одлучио за „It happened in a land of farmers”. Преводилац 3ПН је превео први стих на следећи начин „It came to pass in a land of peasants", преводилац 4SOK ce одлучио за „It was in a land of peasants”, a 5A се одлучио за „It was in a land of farmers”. Констатујемо да преводиоци, приликом превођења на енглески језик, нису користили синтаксичко средство одступања у редоследу основних реченичних елемената ${ }^{6}$, какво налазимо у

6 У репрезентативној и релевантној лингвистичкој литератури се даје ово прецизније одређење „одступање у редоследу основних реченичних елемената" у односу на мање прецизно одређење „промена реда речи” (Mišić Ilić 2004: 13). 
оригиналу („било је то” уместо стандардно уобичајеног „то је било”). Сви преводиоци користе регуларан редослед реченичних елемената („it happened”, „it came to pass” и „it was”).

На лексичком нивоу, преводиоци користе различите преводне еквиваленте за „земљу сељака”. Прецизније, „земља” се углавном преводи као „land” (преводиоци: 2ДК, 3ПН, 4SOK и 5A), док се у преводу 1ЛЛ додатно прецизира додавањем семантичке јединице far-off, па се користи синтагма „far-off land”. Надаље, у погледу семантичке јединице „сељака”, погледаћемо најпре дефинициона одређења у монолингвалном речнику савременог енглеског језика. Лексема farmer одpeђује се на следећи начин у LDOCE-y: „someone who owns or manages a farm”, а лексема peasant, према истом извору, одређује се као „1. а poor famer who owns or rents a small amount of land, either in past times or in poor countries; 2. an insulting word for someone who does not behave politely in social situations or is not well educated". Дакле, на основу значења у речнику, констатујемо да лексема peasant има и додатну негативну конотацију. Преводиоци 1ЛЛ, 3ПН и 4SOK одлучили су се за лекcему peasants, а преводиоци 2ДК и 5 А одлучили су се за лексему farmer. Иако се, на први поглед, може учинити да је лако одабрати преводни еквивалент, то веома често није случај, нарочито пошто „[...] у природним језицима има мало једнозначних речи, па је свест о полисемантичности сваке поједине речи стално присутна, без обзира на манифестно значење једног лексема" (Kremzer 1981: 101).

Затим је следећи стих „на брдовитом Балкану”, преведен на следећи начин. Преводилац 1ЛЛ преводи „among the Balkan hills”, а преводилац 2ДК преводи „оn hilly Balkan far, far away”. Преводилац $3 П Н$ се одлучио за 
„in the hills of the Balkans”, а преводилац 4SOK се одлучио за „in the mountainous Balkans”, док се преводилац 5 А одлучио за „оn the mountainous Balkan”.

Надаље, у српском оригиналу налазимо доминантну фигуру инверзије, која се иначе среће више пута (другова редови иели, задатке тешке, чета малена, тајни родољубивих и љьубавних), и одмах и у првој строфи налазимо инверзију: „умрла је мученичком смрћу чета ђака”. Преводилац 1ЛЛ одлучио се за „where martyrdom befell a class of schoolboys gay". Преводилац 2ДК одлучио се за „а troop of students died martyred”. Преводилац ЗПН одлучио се за „a martyr's death was suffered by a troop of pupils". Преводилац 4SOK одлучио ce за „a company of schoolchildren died a martyr's death", а преводилац $5 \mathrm{~A}$ се одлучио за „where troops of children died martyr death". У преводу 1ЛЛ је преводилац узео у обзир и историјски контекст тиме што је приликом превођења прецизирао информацију (schoolboys), што би се у теоријским оквирима теорије релевантности могло одредити као својеврсна интерпретативна сличност (Rosales Sequeiros 2001: 197).

„У једном дану” преведено је на следећи начин. Преводилац 1ЛЛ одлучио се за „all on one day”. Преводилац 2ДК одлучио се за „оn one single day”, а преводилац $3 П Н$ одлучио се за „in just twenty four hours”. Преводиоци 4SOK и 5А одлучили су се за „in one day”. У погледу риме, код 1ЛЛ видимо да се римују gay и day, а код 2ДК се римују аway и day. Преводиоци $3 П \mathrm{H}, 4 \mathrm{SOK}$ и $5 \mathrm{~A}$ се нису одлучили за риму у првој строфи песме.

7 У теоријском оквиру теорије релевантности, контекст би се могао посматрати као подскуп скупа ментално репрезентованих претпоставки. Надаље, ове претпоставке у међусклопу и садејству са новим језичким подацима омогућавају остваривање когнитивних ефеката. 
Друга строфа српског оригинала почиње одступањем у редоследу основних реченичних елемената ради постизања ефеката: „Исте су године сви били рођени”. Преводилац 1ЛЛ одлучио се за „About the same year were they born”, а преводиоци 2ДК ЗПН, 4SOK и $5 \mathrm{~A}$ одлучили су се за „They were all born in the same year". Дакле, видимо да само 1ЛЛ приликом превода користи сличне ефекте као што су синтаксички испољени у оригиналној српској верзији.

Стих „Исто су им текли школски дани” преведен је на различите начине. Преводилац 1ЛЛ одлучио се за „Same were the days at school they spent”. Преводилац 2ДК одлучио се за „For all of them, the school days were the same”. Преводилац 3ПН одлучио се за „their timetables were the same shape and size", односно констатујемо оно што се у теорији релевантности назива обогаћење приликом превођења. Другим речима, чини се, да је преводилац 3ПН путем прагматичког инференцијалног процеса обогаћења проширио језички декодирану логичку форму исказа приликом превођења. Преводилац 4SOK одлучио се за „their school days passed the same”, а преводилац 5А одлучио се за „their school days were flowing similarly". Дакле, констатујемо да су сви преводиоци превели овај стих на различит начин, макар када је у питању синтаксичко устројство, што све укупно доводи до разноврсности и богатства различитих превода ове песме на енглески језик.

Остатак строфе, у оригиналу, на српском језику гласи: „На исте свечаности заједно су вођени, од истих болести сви пелцовани, и сви умрли у истом дану". Управо у овом делу видимо да ово није класична бајка, пошто нема happy end, иначе карактеристичан за бајке. Преводилац 1ЛЛ се одлучио за "same the celebrations to which they went; same was 
the day of vaccination, and same the day their lives were spent”. Преводилац 2ДК се одлучио за „They were all taken to the same festivals with cheer, they were all vaccinated until the last name, and they all died on the same day”. Преводилац $3 П Н$ се одлучио за „they were all taken to the same ceremonies, 'gainst the same maladies immunized, and all died on the same day". Преводилац $4 \mathrm{SOK}$ се одлучио за „taken together to the same festivities, vaccinated against the same diseases, and all died on the same day", а преводилац 5 A се одлучио за "they participated in the same ceremonies, they caught the same diseases, and they all died on the same day".

Стих који садржи инверзије (седела је у ђачкој клупи, чета малена, задатке тешке) и који садржи уметање говора наставника на часу (колико може путник ако иде пешке), у оригиналу Десанке Максимовић гласи:

А педесет и пет минути, Пре смртног трена,

Седела је у ђачкој клупи,

Чета малена,

И исте задатке тешке,

Решавала: колико може

Путник ако иде пешке...

И тако редом.

Преводилац 1ЛЛ се одлучио за:

Five and fifty minutes back before the fatal hour still at their desks they sat, a company of bodies small, 
with eager answers to all

those questions difficult: How much

if a traveller went on foot...

and many, many such.

Преводилац 2ДК се одлучио за:

And only fifty-five minutes

prior the death moment,

a small troop of fidgets

sat beside their school desks

solving the same hard math quest:

"If a traveler goes by foot,

how much time he needs to rest..."

and so on.

Преводилац 3ПН се одлучио за:

And just fifty five minutes

before the deathly toll

the tiny troop was sitting

at their desks in their rows

wrestling with the brain

exercises: from two stations

leave two trains...

and so it goes.

Преводилац 4SOK се одлучио за:

And fifty-five minutes

before the moment of death

the company of small ones

sat at its desk

and the same difficult assignments 
they solved: how far can a traveler go if he is on foot... and so on.

\section{Преводилац 5А се одлучио за:}

And fifty-five minutes before the mortal moment the whole group of children were sitting in the school bench and were solving the same tasks difficult tasks, And how is it possible that they are going now in such queue.

Погледаћемо како су преведени следећи стихови: „Мисли су им биле пуне истих бројки, и по свескама у школској торби бесмислених лежало безброј петица и двојки”. Преводилац 1ЛЛ се одлучио за „Their thoughts were full of figures; their satchels full of copy-books with marks both good and bad”. Преводилац 2ДК се одлучио за „Their thoughts were filled with same figures and tags and there was a countless amount of senseless As and Fs in their notebooks and in their bags". Преводилац 3ПН се одлучио за „Their thoughts were full of the same mysteries and senselessly scattered around the benches were A's and D's". Преводилац 4SOK се одлучио за „Their thoughts were full of the same numbers and throughout their notebooks in school bags lay an infinite number of senseless A's and F's." Преводилац 5A се одлучио за „They had much thoughts and their notebooks in the school bags useless there were countless fives and twos". За превођење овог дела потребно је призвати контекст и прагматику у помоћ. Наиме, у то доба, најнижа оцена је била двојка, па у тексту ори- 
гинала налазимо опозицију петице-двојке, а у преводу налазимо различита решења која су сва прихватљива из угла теорије релевантности пошавиши од директног превода 5A (fives and twos) па преко превода у коме је деловао механизам обогаћења код 4SOK (A's and F's).

Погледаћемо како су преводиоци превели „Прегршт истих снова и истих тајни родољубивих и љубавних стискали су у дну џепова”. Преводилац 1ЛЛ се одлучио за „a handful of dreams and secrets, of love and loyalty, stuffed into their pockets”. Преводилац 2ДК се одлучио за „They were squeezing a whole bunch of secrets that mattered - either patriotic or a love letter - on the bottom of their pockets”. Преводилац $3 П Н$ се одлучио за „Handfulls of shared dreams and shared secrets patriotic and romantic were clenched tightly in their fists”. Преводилац $4 \mathrm{SOK}$ се одлучио за „A pile of the same dreams and the same secrets patriotic and romantic they clenched in the depths of their pockets". Преводилац 5A се одлучио за „They had the same dreams and same secrets, patriotic ones and loving ones, same things in their pockets".

Следећи стихови, „И чинило се сваком да ће дуго да ће врло дуго трчати испод свода плава док све задатке на свету не посвршава”, преведени су на следећи начин. Преводилац 1ЛЛ се одлучио за „And it seemed to each of them that still for long, for very long, they would all run beneath the sun, until their tasks were done", у коме се примећује римовање (sun - done), а и у оригиналу имамо риму (плава - посвршава). Преводилац 2ДК се одлучио за „And everyone of them supposed that he would for a long time, for a very, very long time run under the blue sky - until all math quests on the world were done and gone by”, где исто примећујемо риму (sky - gone by). Преводилац ЗПН се одлучио за „And each imagined that for a long time, for a really long time they would run 'neath the canopy 
blue 'til all the exercises in the world were through", у коме исто примећујемо римовање (blue - through). Преводилац $4 \mathrm{SOK}$ се одлучио за „and it seemed to everyone that they will run for a long time beneath the blue arch until all the assignments in the world are completed". Преводилац $5 \mathrm{~A}$ се одлучио за „And it seemed to everybody that they will run under the blue sky for long, very long time until all tasks in the world they will solve".

Погледаћемо и како је преведена последња строфа, која у оригиналу гласи: „Дечака редови цели узели се за руке и са школског задњег часа на стрељање пошли мирно као да смрт није ништа. Другова редови цели истог часа се узнели до вечног боравишта". Преводилац 1ЛЛ се одлучио за „Out came the classmates small holding each other by the hand; their lessons but half done, to the shooting place they went in silence - death to face: schoolboys small, one and all, send to their eternal dwelling-place”. Преводилац 2ДК се одлучио за „Whole rows of boys took each other's hands and leaving the last school class went to the execution quietly, as the death was nothing but a smile. All friends in rows were, at the same moment, lifted up to the eternal domicile". Преводилац ЗПН се одлучио за „Entire rows of boys took each other by the hand and from the last class at school went calmly to their executions as if death was nothing. Entire rows of friends in the same instant rose to an eternal dwelling". Преводилац 4SOK се одлучио за „Whole rows of boys took each other by the hand and from their last class went peacefully to slaughter as if death was nothing. Whole lines of friends ascended at the same moment to their eternal residence”. Преводилац 5A се одлучио за „And a row of children holding the hands of each other, from the last schol lesson went to the execution, such peaceful as the death were nothing. And a row of friends in the same hour 
were sent to eternal rest”. Регистровали смо риму само код 1ЛЛ (small - one and all). Погледаћемо како су преводиоци превели синтагму „вечно боравиште”. 1ЛЛ се одлучио за „eternal dwelling-place”, 2ДК за „the eternal domicile”, 3ПН за „an eternal dwelling”, 4SOK за „eternal residence”, а преводилац 5А се одлучио за „eternal rest”.

Дакле, видимо да су преводиоци на различите начине пренели оригиналну мисао Десанкину, и то свако на свој начин, више или мање успешно. Иако смо у овом раду анализирали више превода песме Крвава бајка Десанке Максимовић (а нисмо узели у обзир и друге песме), сматрамо да је узорак статистички ваљан да би наша уопштавања била валидна. У наредном делу ћемо погледати извесне закључне напомене.

\section{3. Закључне напомене}

Превођење песме Крвава бајка Десанке Максимовић на енглески језик можда се, у првом тренутку, може учинити као нешто што није изузетно захтевно, међутим, анализом пет превода песме Крвава бајка на енглески језик видели смо да је превођење песме Крвава бајка Десанке Максимовић изузетно комплексно. Самим тим, изводи се закључак да је изузетно захтевно преводити поезију Десанке Максимовић на енглески језик, а да преводилац при том покуша да сачува дух оригинала. Преводи су испољили разлике на различитим нивоима, синтаксичком, семантичком, стилском, али су преводиоци увек покушали да задрже дух оригиналне песме. Преводиоци каткад користе и решења која прагматички проширују преводне еквиваленте оригиналних концепата, нарочито на лексичком нивоу. Ово и није зачуђујуће, пошто се у превођењу поезије 
може користити и прагматички обогаћен превод. Овде је релевантно споменути и контекст, који се понекада призива у помоћ приликом доношења одлуке у вези са одговарајућим енглеским преводним еквивалентом.

Још један налаз, до кога се дошло приликом анализе пет превода песме Крвава бајка на енглески језик, показао је да преводиоци поштују стилске фигуре и синтактичко устројство српског оригинала, у оној мери у којој је то могуће. У погледу риме, мањи број преводилаца је покушао да пренесе дух риме оригинала, али то и јесте изазов и представља тежи задатак.

Примењујући један еклектички теоријски модел, али превасходно се ослањајући на теорију релевантности и структуралистичку поетику (у ширем смислу), испитали смо извесне могућности примене когнитивног принципа релевантности и то у превођењу конкретног концептуалног језичког материјала ексцерпираног из песме Крвава бајка Десанке Максимовић. Анализирајући пет превода на енглески, приметили смо да преводиоци понекада прагматички обогаћују језичке изразе који кодирају концептуалне податке (нпр. were clenched tightly in their fists; ascended at the same moment; a small troop of fidgets). Преводиоци у анализираних пет превода песме Крвава бајка прагматички обогаћују исказе у циљу добијања пропозиционих конституената исказа које је оригинални текст песме намеравао да саопшти (нпр. на стрельане пошли мирно; стискали су у дну цепова; од истих болести сви пелцовани).

Нужно је поменути да су, приликом анализе пет превода песме Крвава бајка на енглески језик, узете у обзир и експликатуре, као својеврсни семантичко-прагматички хибриди. Узимање експликатуре у обзир нарочито је важно пошто обогаћење и засићење, између осталог, учествују у грађењу експликатуре. По- 
клоњена је пажња семантичкој верзији процеса обогаћења. Сем тога, анализа превода речи, барем оних које су се нашле под нашом истраживачком лупом у овом раду, може да се употреби „[...] као ослонац за анализу семантичких вредности речи у оригиналу” (Vukobrat 1986: 163).

Сви анализирани преводи песме Крвава бајка могу нам пружити извесне спознаје, макар када је у питању превођење поезије Десанке Максимовић, или уопштеније, превођење њене поезије са српског на енглески језик. Свакако, у ширем смислу, неки делови анализе превода поезије могли би да имају и даље реперкусије у домену транслатологије.

На крају, иако „превод ни издалека није тако дугог века као оригинал [...]” (Grubačić 1981: 193), „у процесу поетске метемпсихозе [...] преводилац пружа уточиште генију" (Konstantinović 1981: 139). У том смислу, сматрамо да ће будућа истраживања ширег корпуса песама Десанке Максимовић свакако пружити подстицаје за проучавање превода и на друге језике, а истовремено обезбедити и извесне спознаје у домену транслатологије, или макар оног њеног дела посвећеног превођењу поезије.

\section{Извори и литература:}

Bertolino, Nikola. „O kritici prevoda poetskih dela”. Ljubiša Rajić (ur.). Teorija i poetika prevođenja. Beograd: Prosveta, 1981. 159-176. Штампано.

Born, Anne. "The undefinitive translation of poetry". Mladen Jovanović (ed.). Translation, a Creative Profession: XIIth World Congress of FIT / La traduction, profession créative: XIIe Congres mondial de la FIT. Belgrade: Association of Scientific and Technical Translators of Yugoslavia, PrEvodiLAC and FIT 
- Fédération Internationale des Traducteurs / International

Federation of Translators, 1990. 227-234. Штампано.

Bugarski, Ranko. Uvod u opštu lingvistiku. Sabrana dela: Knjiga 6.

Beograd: Čigoja \& XX vek, 1996. Штампано.

Delas, Daniel. "La grammaire générative rencontre la figure".

Poétique générative par Daniel Delas \& Jean-Jacques Thomas.

Paris: Didier \& Larousse. LANGAGES 51 (1978): 65-104. Штампано.

Đurić, Miloš D. \& Nada Krnjaić-Cekić. „Glosar teorije relevantnosti: srpsko-engleski”. PREVODILAC 76 (2016): 148151. Штампано.

GCE: Quirk, Randolph et al. A Grammar of Contemporary English. London: Longman, 1974. Штампано.

Grubačić, Slobodan. „Prevod i književna istorija”. Ljubiša Rajić (ur.). Teorija i poetika prevođenja. Beograd: Prosveta, 1981. 177-200. Штампано.

Gutt, Ernst-August. "A theoretical account of translation without a translation theory". Target - International Journal of Translation Studies 2 (1990): 135-164.

Hlebec, Boris. Opšta načela prevođenja. Beograd: Naučna knjiga, 1989. Штампано.

Jones, Francis R. “The translation of poetry”. Kirsten Malmkjær \& Kevin Windle (eds.). The Oxford Handbook of Translation Studies. Oxford: Oxford University Press, 2011. 1-14.

Калер, Џонатан. Структуралистичка поетика: Структурализам, лингвистика и проучаване книжевности. Београд: Српска књижевна задруга, 1990. Штампано.

Kremzer, Nikola. „Semantičke relacije na intra- i interlingvističkom planu". Ljubiša Rajić (ur.). Teorija i poetika prevođenja. Beograd: Prosveta, 1981. 101-118. Штампано. Konstantinović, Radivoje. „O prevođenju poezije”. Ljubiša Rajić (ur.). Teorija i poetika prevođenja. Beograd: Prosveta, 1981. 119-139. Штампано.

LDOCE: Longman Dictionary of Contemporary English. Fifth Edition. London: Pearson Education Limited, 2009. Штампано.

Maksimović, Desanka. Don't Fear. Selected Poems. Belgrade: Association of Writers of Serbia, 1998. Штампано. 
Марковић, Љиљана. „Тема љубави у поезији Десанке Максимовић и јапанских песникиња". Александра Вранеш (ур.). Српске песникиғее. Андрићград - Вишеград \& Београд: Андрићев институт \& Задужбина „Десанка Максимовић”, 2018. 115-122. Штампано.

Markus, Solomon. Matematička poetika. Beograd: Nolit, 1974. Штампано.

Mateo, José. "Contrasting relevance in poetry translation". Perspectives: Studies in Translatology 17:1 (2009): 1-14. Штампано.

Mišić Ilić, Biljana. Diskursne funkcije reda reči u engleskom jeziku. Niš: Filozofski fakultet u Nišu \& Prosveta, 2004. Штампано.

Polovina, Vesna. Prilozi za kognitivnu lingvistiku. Beograd: Filološki fakultet, 1996. Штампано.

Rosales Sequeiros, José. "Types and degrees of interpretive resemblance in translation". Revista Alicantina de Estudios Ingleses 14 (2001): 197-211. Штампано.

Сибиновић, Миодраг. Оригинал и превод: Увод у историју и теорију превођења. Београд: Привредна штампа, 1979. Штампано.

Solar, Milivoj. Teorija književnosti. VI neizmenjeno izdanje. Zagreb: Školska knjiga, 1981. Штампано.

Sperber, Dan \& Deirdre Wilson. Relevance: Communication and Cognition. Reprinted Edition. Oxford: Basil Blackwell, 1988. Штампано.

Sperber, Dan \& Deirdre Wilson. Relevance: Communication and Cognition. Second Edition. Oxford: Basil Blackwell, 1995. Штампано.

Tanasescu, Raluca. "Poetry as a heuristic object of discourse in translation theory. Preliminary notes for the resurrection of poetry translation in the age of globalization". Paralléles 28(2) (2016): 1-21. Штампано.

Thomas, Jean-Jacques. "Théorie générative et poétique littéraire”. Poétique générative par Daniel Delas \& Jean-Jacques Thomas. Paris: Didier \& Larousse. LANGAGES 51 (1978): 7-64. Штампано.

Tomović, Nenad. „Terminologija primenjene lingvistike: engleskosrpski”. PREVODILAC 63 (2010): 125-148. Штампано. 
Шеатовић, Светлана. „Поезија Десанке Максимовић и Ане Ристовић - Облици аутохтоног песничког развоја”. Александра Вранеш (ур.). Српске песникиюе. Андрићград - Вишеград \& Београд: Андрићев институт \& Задужбина „Десанка Максимовић“, 2018. 67-88. Штампано. Vukobrat, Slobodan. „Poezija, prevod i nastava jezika”. Radmilo Marojević (ur.). Prevođenje poezije i nastava stranih jezika. Beograd: Udruženje naučnih i stručnih prevodilaca Srbije \& Društvo za primenjenu lingvistiku Srbije, 1986. Штампано. Žegarac, Vladimir. Osnovi teorije relevantnosti. Beograd: Odsek za opštu lingvistiku, Filološki fakultet, Univerzitet u Beogradu, 2005. Штампано.

Živković, Dragiša. Teorija književnosti sa teorijom pismenosti. Beograd \& Novi Sad: Zavod za udžbenike i nastavna sredstva \& Zavod za izdavanje udžbenika, 1992. Штампано.

\section{Miloš D. Đurić}

\section{TRANSLATING THE POETRY OF DESANKA MAKSIMOVIĆ FROM SERBIAN INTO ENGLISH}

The aim of this paper is to describe and investigate five English translations of the Serbian poem Krvava bajka, written by Desanka Maksimović. The paper consists of three parts. Part 1 introduces the scope, theoretical framework and corpusbased data. Furthermore, the author surveys current research on translation process in general and poetry translation in particular. Additionally, in this part of the study, the author summarises certain tenets of diverse poetics types pertinent to the subject, namely, Generative poetics, Mathematical poetics, Structuralist poetics. My analysis is also based on Relevance Theory, more precisely, relevance-theoretic approach to cognition. Pragmatically-based approach to translation is also included in the pertinent analysis.

Part 2 is the analysis of five translations of the poem Krvava bajka. This part analyses a number of cases in Serbian-English 
translations in order to illustrate mostly lexical-pragmatic processes employed by five translators. At the same time, in this part, we explore certain implications of relevance-theoretic approach to poetry translation. Some translators have applied the pragmatically-based approach to translation in order to solve coding-inferential challenges posed by the target language. The analysed translational equivalents illustrate a number of lexicalpragmatic processes of what is encoded and what is actually communicated by the poet Desanka Maksimović.

Part 3 lists the most relevant findings, discusses the applicability of the employed theoretical models, and provides concluding remarks.

Key words: Desanka Maksimović, Poetry, Translating Poetry, Translational Equivalents, Krvava bajka, Relevance Theory, Structuralist Poetics, Pragmatic Enrichment. 